\title{
Analisis Akuntabilitas Kinerja Instansi Pemerintah Kota Baubau (Studi Kasus pada Inspektorat Daerah Kota Baubau)
}

\author{
Endang Tri Pratiwi ${ }^{1 *}$, Dewi Mahmuda ${ }^{1}$, Ernawati Malik ${ }^{1}$ \\ ${ }^{1}$ Universitas Muhammadiyah Buton, Indonesia \\ *Korespondensi: endangtripratiwi12@gmail.com
}

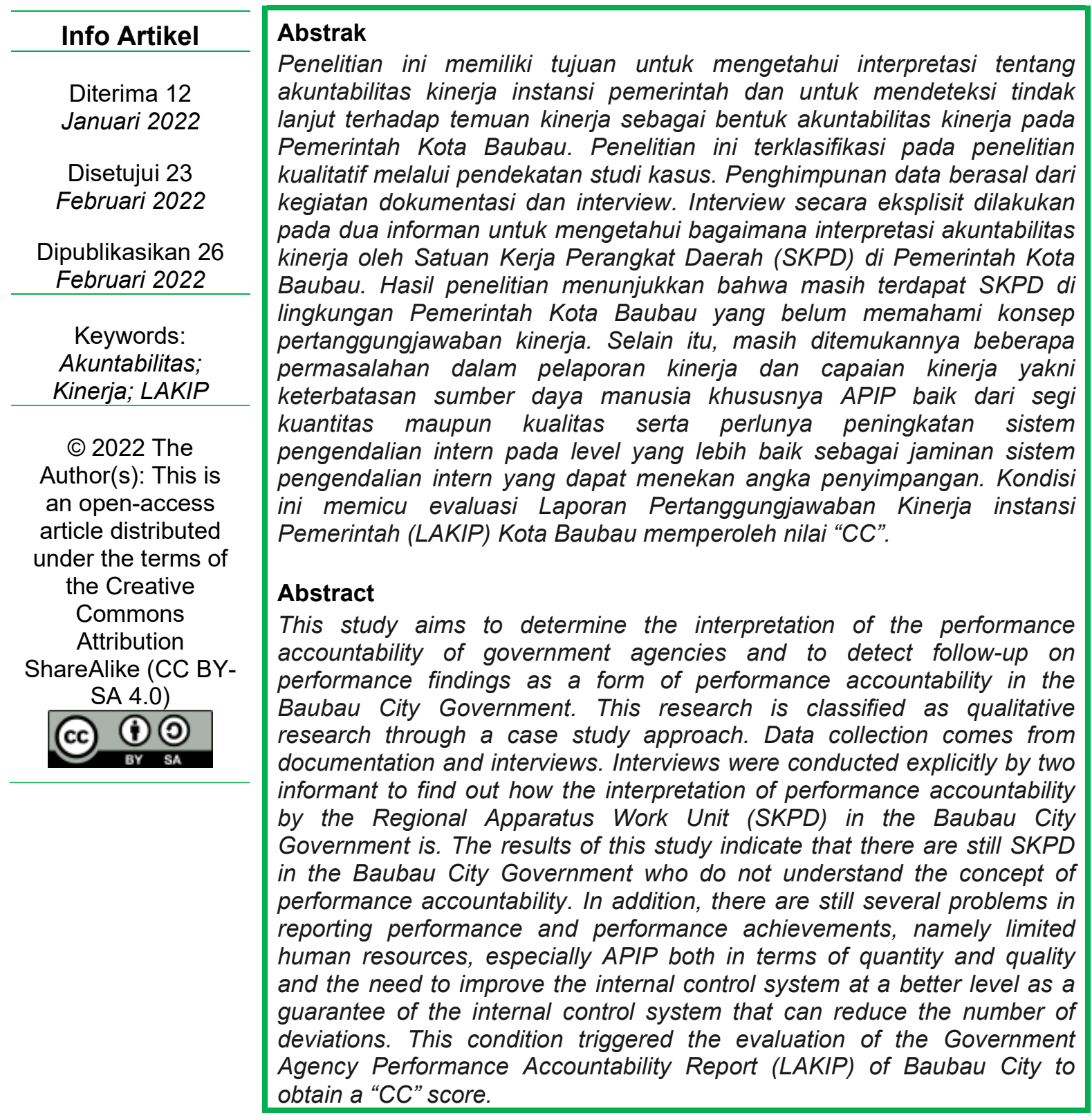




\section{Pendahuluan}

Isu kinerja pemerintah daerah saat ini menjadi sorotan publik karena belum menunjukkan hasil yang baik yang dirasakan masyarakat. Rakyat menuntut agar pemerintah memiliki kinerja yang baik dalam menjalankan tugas dan tanggung jawabnya sebagai perwujudan dari konsep otonomi daerah (Chaidir Iswanaji, Siti Afidatul Khotijah, 2021). Pada prinsipnya pembangunan daerah bertujuan untuk memberdayakan masyarakat secara keseluruhan, melalui peningkatan kapasitas pemerintah daerah agar mampu memanfaatkan sumber daya yang ada baik dari pelayanan pemerintah, kemampuan sosial ekonomi masyarakat, maupun sumber daya alam di wilayah tersebut. Untuk mencapai tujuan ini secara efektif, pemerintah daerah telah diberikan kekuasaan yang lebih luas melalui otonomi daerah. Dengan demikian, pemerintah daerah dapat mengurangi ketergantungan terhadap bantuan atau subsidi dana dari pemerintah pusat (Pratiwi et al., 2020).

Performance terhadap instansi pemerintah merupakan representasi tentang tingkat pencapaian sasaran ataupun goals sebagai bentuk dari pendefinisian visi, misi dan strategi dari instansi pemerintah. Kondisi ini mengisyaratkan taraf atau tingkatan keberhasilan dan kegagalan atas pengimplementasian program/kegiatan berdasarkan penetapan program/kegiatan tersebut. Keberhasilan tersebut diukur melalui indikator (outcome) yakni standar yang merefleksikan adanya suatu fungsi dari proogram/kegiatan atau (output) yakni standar barang dan jasa yang diperoleh dalam suatu program/kegiatan guna mendukung tercapainya sasaran dan tujuan dari suatu policy (Waworuntu, 2014).

Era ini, sistem dalam manajemen pemerintah berfokus pada ekskalasi pertanggungjawaban serta ekskalasi performance yang memiliki arah pada output,sehingga performance menjadi hal penting dalam pemberian pelayanan publik bagi instansi pemerintah. Namun dalam praktiknya, kinerja yang dilakukan kontra dengan konsep yang disusun (Ristyana Ria, 2016). Problema kinerja di berbagai daerah khususnya kinerja pegawai yang akan berdampak pada kinerja organisasi dalam hal ini kinerja instansi pemerintah, antara lain: masih terdapat pegawai yang belum mampu menjabarkan tentang konsep kinerja yang ingin dicapai, sebatas hanya menggugurkan kewajiban pekerjaannya sesuai dengan tugas pokok dan fungsinya tanpa memandang outcome dan performance output yang telah dilakukan. Selain itu, peran pengawas daerah dalam melaksanakan tugas pemeriksaan belum begitu baik dan sesuai dengan standar pemeriksaan di masing-masing SKPD, sehingga hasil pemeriksaan menjadi kurang efektif (Pratiwi, 2019). Permasalahan mengenai kinerja instansi pemerintah mendesak Pemerintah Indonesia dapat memaksimalkan performance terhadap instansi pemerintah. Salah satu upaya pemaksimalan kinerja tersebut adalah dengan mengimplementasikan Laporan Akuntabilitas Kinerja Instansi/Lembaga/Badan Pemerintah, disingkat LAKIP.

Pelaksanaan sistem pengukuran kinerja pemerintah telah diatur dalam Instruksi Presiden Nomor 7 Tahun 1999 tentang Akuntabilitas Kinerja Instansi Pemerintah (AKIP) dan Keputusan Badan Tata Usaha Negara (LAN) Nomor 589/IX/6/Y/ Tahun 1999 tentang Pedoman Pelaporan Pertanggungjawaban Kinerja Instansi Pemerintah yang disempurnakan dari Surat Keputusan Badan Administrasi Negara (LAN) No. 239/IX/6/8/2003 disebutkan bahwa Laporan Pertanggungjawaban Kinerja Instansi Pemerintah (LAKIP) merupakan alat untuk melaksanakan akuntabilitas kinerja yang akan dinilai secara transparan, 
sistematis, dan akuntabel. Seperti yang tertuang pada Peratuhan Pemerintah No. 60 Tahun 2008 tentang sistem pengendalian intern pemerintah, pengimplementasian terhadap pengendalian intern tersebut dijalankan oleh aparat pengawasan intern pemerintah (APIP), yakni BPKP, Inspektorat Jenderal, Inspektorat Provinsi dan Inspektorat Kabupaten/Kota (Januar, 2014).

Pemilihan Inspektorat Daerah Kota Baubau sebagai lokasi penelitian dikarenakan organisasi Inspektorat Daerah Kota Baubau yang merupakan pengawas internal dalam lingkup penyelenggaraan pemerintahan daerah Kota Baubau berdasarkan Peraturan Daerah Nomor 25 Tahun 2017. Dalam menjalankan tugasnya dan fungsinya, Inspektorat Daerah Kota Baubau wajib berperan aktif dalam menindaklanjuti setiap pengaduan masyarakat atau pelimpahan wewenang dari Inspektur Jenderal Kementerian Dalam Negeri, Sekretariat Negara, Menteri Pendayagunaan Aparatur Negara dan Badan Aparatur Sipil Negara. Selain itu, Inspektorat Daerah Kota Baubau merupakan unsur pengawasan dalam Struktur Organisasi Pemerintah Daerah, dimana dalam melaksanakan tugas Pembinaan dan Pengawasan terhadap semua Organisasi Perangkat Daerah (OPD) di Lingkungan Pemerintah Kota Baubau. Sejak tahun 2015-2020 Opini BPK RI terhadap LKPD Pemerintah Kota Baubau memperoleh opini Wajar Tanpa Pengecualian (WTP) secara berturut-turut selama 6 tahun. Meski memperoleh opini WTP, temuan BPK tetap masih ada. Kondisi ini mencerminkan masih perlunya peran pengawasan dan pemantauan Inspektorat Daerah dalam menunjang kinerja SKPD. Selain itu, berdasarkan LAKIP Tahun 2019, masih terdapat SKPD yang belum mengumpulkan LAKIP-nya secara tepat waktu. Berdasarkan uraian tersebut, tujuan penelitian ini untuk mengetahui interpretasi tentang akuntabilitas kinerja terhadap instansi pemerintah dan untuk mendeteksi tindak lanjut terhadap temuan kinerja sebagai bentuk akuntabilitas kinerja pada Pemerintah Kota Baubau (Studi Kasus di Inspektorat Daerah Kota Baubau.

\section{Metode Penelitian}

Jenis penelitian ini menggunakan penelitian kualitatif dengan pendekatan studi kasus. Jenis data yang digunakan adalah data primer. Tujuan penggunaan data primer adalah untuk menjamin keandalan dan kebaruan informasi yang diperoleh. Data primer berasal dari kegiatan interview secara eksplisit dan dokumentasi. Narasumber dalam proses interview yakni inspektur dan kepala sub bagian perencanaan, keuangan dan evaluasi Inspektorat Daerah Kota Baubau. Sedangkan kegiatan dokumentasi dalam penelitian ini adalah menemukan dan mendeskripsikan data/informasi terkait akuntabilitas kinerja berupa LAKIP Inspektorat Daerah Kota Baubau Tahun 2019-2020, dokumen Rencana Pembangunan Jangka Menengah Kota Baubau Tahun 2018-2023, dan dokumen pendukung lainnya. Teknik analisis data menggunakan langkah-langkah analisis dari hasil penelitian Miles dan Huberman, seperti yang tergambar pada Gambar 1 berikut ini. 


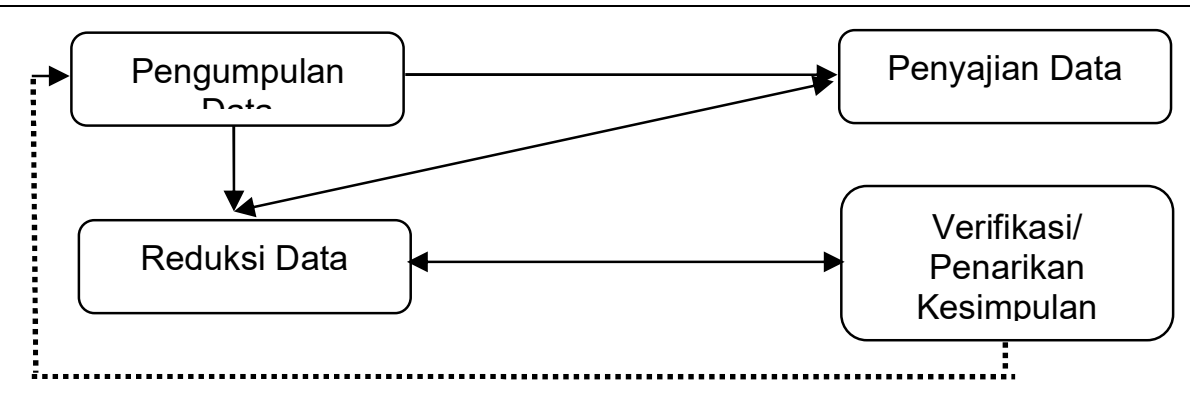

Gambar 1. Diagram Alur Penelitian Kualitatif Menurut Miles dan Huberman

\section{Hasil dan Pembahasan}

\subsection{Gambaran Umum Inspektorat Daerah Kota Baubau}

Inspektorat Daerah Kota Baubau adalah organisasi perangkat daerah yang merupakan pengawas internal yang berada dalam lingkup penyelenggaraan pemerintahan daerah Kota Baubau berdasarkan Perda Nomor 25 tahun 2017. Inspektorat mempunyai tugas membantu Walikota dalam melakukan pengawasan terhadap pelaksanaan urusan pemerintahan daerah (M. Zidny Nafi' Hasbi, 2019). Dalam pelaksanaan pengawasan Inspektorat dipimpin oleh Inspektur dibantu oleh 4 orang pejabat struktural eselon III dan 2 orang pejabat struktural eselon IV serta pejabat fungsional 13 orang dan staf sebanyak 13 orang. Salah satu bagian dari struktur organisasi Inspektorat yaitu Sekretariat yang dipimpin oleh Sekretaris. Dalam menjalankan tugas dan fungsinya Inspektorat Daerah Kota Baubau dituntut untuk berperan aktif dalam menindak lanjuti setiap adanya pengaduan masyarakat maupun limpahan kewenangan dari Irjen Kemendagri maupun,Setneg dan MenPAN serta BKN.

Visi Kepala Daerah dalam hal ini Walikota Baubau yang tertuang dalam RPJMD 2018-2023 yaitu "Mewujudkan Baubau yang Maju, Sejahtera dan Berbudaya". Misi yang dilaksanakan oleh Inspektorat Daerah Kota Baubau guna mewujudkan visi Kepala Daerah adalah "Terwujudnya Lembaga Pengawasan Internal yang Profesional dalam rangka Mewujudkan Good Governance", maka untuk mendukung tercapainya misi tersebut Inspektorat Daerah Kota Baubau menetapkan tujuan serta sasaran strategis. Inspektorat Daerah Kota Baubau menetapkan tujuan untuk "Meningkatkan akuntabilitas dan transparansi penyelenggaraan pemerintahan". Sedangkan sasaran strategis yang hendak dicapai atau dihasilkan dalam kurun waktu lima tahun berdasarkan tujuan adalah a) Meningkatnya Kualitas Pengawasan dan Pembinaan lingkup Internal, dan b) Meningkatnya Kualitas Sumber Daya Manusia dan Kapabilitas APIP. Berikut adalah perbandingan sasaran kondisi awal dan target akhir pada Inspektorat Daerah Kota Baubau yang termuat pada Tabel 1.

Tabel 1. Perbandingan Sasaran Kondisi Awal dan Target Akhir

\begin{tabular}{|c|c|c|c|c|c|}
\hline No & Sasaran Strategis & $\begin{array}{l}\text { Indikator Kinerja } \\
\text { Utama (IKU) }\end{array}$ & Satuan & $\begin{array}{l}\text { Kondisi } \\
\text { Awal } \\
\text { (2018) }\end{array}$ & $\begin{array}{l}\text { Target } \\
\text { Akhir } \\
\text { (2023) }\end{array}$ \\
\hline \multirow[t]{2}{*}{1} & \multirow{2}{*}{$\begin{array}{l}\text { Meningkatnya Kualitas } \\
\text { Pengawasan dan } \\
\text { Pembinaan Lingkup } \\
\text { Internal }\end{array}$} & $\begin{array}{l}\text { Persentase Tindak } \\
\text { Lanjut Hasil } \\
\text { Pemeriksaan BPK }\end{array}$ & $\%$ & 75,68 & 85 \\
\hline & & $\begin{array}{l}\text { Persentase Nilai } \\
\text { SAKIP OPD Minimal }\end{array}$ & $\%$ & 65 & 85 \\
\hline
\end{tabular}




\begin{tabular}{llllll}
\hline & & CC & & & \\
\hline 2 & Meningkatnya Kualitas & Level Maturitas SPIP & Level & 2 & 4 \\
\cline { 2 - 5 } & $\begin{array}{l}\text { APIP \& Efektifitas SPIP } \\
\text { dalam Rangka }\end{array}$ & Level Kapabilitas & Level & 2 & 4 \\
$\begin{array}{l}\text { Profesionalisme } \\
\text { Pengawasan Internal }\end{array}$ & APIP & & & \\
\hline
\end{tabular}

Sumber: LAKIP Kota Baubau Tahun 2019.

\subsection{Pemahaman Akuntabilitas Kinerja}

Pemahaman akuntabilitas kinerja dijabarkan melalui dua sasaran strategis. Sasaran strategis pertama adalah peningkatan kualitas sumber daya manusia dan kapabilitas APIP (Aparat Pengawasan Intern Pemerintah). Berdasarkan hasil wawancara yang dilakukan dengan Inspektorat pada Inspektorat Daerah Kota Baubau, disebutkan bahwa peningkatan Kualitas APIP dan Efektivitas SPIP Dalam Rangka Profesional Pengawasan Internal diukur dengan indikator kinerja yaitu Kematangan SPIP Level dan Kemampuan APIP.

Peningkatan kualitas sumber daya manusia dan kapabilitas APIP (Aparat Pengawasan Intern Pemerintah) yang diukur dengan indikator pertama adalah kinerja Persentase Penurunan Temuan Pemeriksaan Internal (Inspektorat Daerah), Persentase Penyelesaian Tindak Lanjut Eksternal (BPK R.I), Persentase SKPD Lingkup Pemerintah Daerah Kota Baubau yang Mendapatkan Predikat Sistem AKIP $\geq$ CC dan Penanganan Kasus Pengaduan Masyarakat sepenuhnya telah memenuhi target yang ditetapkan dan ada yang bahkan melewati target. Utamanya dari sisi penyelesaian tindak lanjut hasil pemeriksaan eksternal (BPK R.I) dan jumlah SKPD di lingkungan Pemerintah Daerah Kota Baubau yang mendapatkan Predikat Sistem AKIP $\geq$ CC serta indikator kinerja penurunan temuan hasil pemeriksaan internal (Inspektorat Daerah) di lingkungan Pemerintah Daerah Kota Baubau setelah tahun sebelumnya sempat mengalami penurunan capaian kinerja namun kini telah melampaui target yang telah dicanangkan. Kondisi ini terurai pada gambar 2 dan tabel 1 di bawah ini.

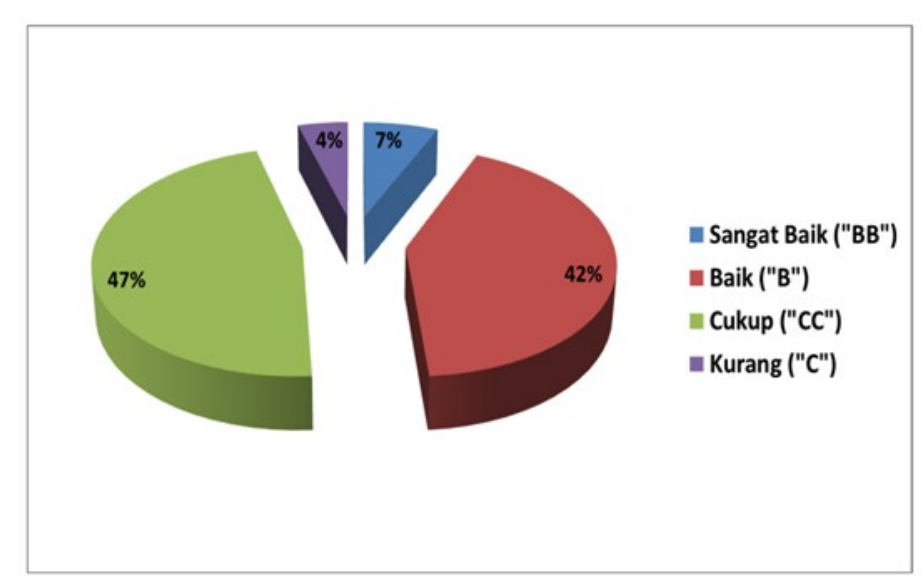

Gambar 2. Persentase SKPD di Lingkup Pemerintah Kota Baubau yang memperoleh Predikat Sistem AKIP CC Tahun 2019 
Tabel 2. Persentase Penyelesaian Tindak Lanjut Hasil Pemeriksaan BPK RI

\begin{tabular}{cccc}
\hline Selesai & $\begin{array}{c}\text { Dalam } \\
\text { Proses }\end{array}$ & $\begin{array}{c}\text { Belum } \\
\text { Selesai }\end{array}$ & $\begin{array}{c}\text { Tidak dapat } \\
\text { ditindaklanjuti dengan } \\
\text { alasan yang sah }\end{array}$ \\
\hline $63,29 \%$ & $30,49 \%$ & $0,37 \%$ & $6,24 \%$ \\
\hline
\end{tabular}

Sumber: LAKIP Kota Baubau Tahun 2019.

Sasaran strategis kedua adalah Peningkatan kualitas APIP dan efektifitas SPIP dalam rangka profesionalisme pengawasan internal yang diukur dengan indikator kedua adalah Level Maturitas SPIP dan Level Kapabilitas APIP. Berdasarkan hasil QA Tim Asesor BPKP Nomor LSPIP Berdasarkan hasil QA Tim Asesor BPKP Nomor LSPIP513/PW20//3/2019 tanggal 11 November 2019, penjenjangan Kematangan SPIP Inspektorat Daerah Kota Baubau sudah mendekati target yang ditetapkan dalam Performance Agreement yaitu mendapatkan skor penilaian pada Level 2, serta untuk Kapabilitas APIP berdasarkan Asesmen yang dilakukan oleh tim Asesmen BPKP juga telah mencapai target yang telah ditetapkan yaitu beberapa Key Process Area (KPA) dari semua elemen berada pada Level 3 namun beberapa elemen lainnya belum memenuhi level 3 atau berada pada level 2 sehingga skor penilaian akhir untuk Kemampuan Inspektorat APIP Wilayah Kota Baubau masih berada pada level 2. Kemampuan APIP Inspektorat Wilayah Kota Baubau pada level 2 berarti APIP mampu memberikan jaminan yang memadai, memberikan proses yang sesuai dengan peraturan, dan mampu mendeteksi terjadinya korupsi. Kondisi ini tergambar pada Gambar 3 dibawah ini.

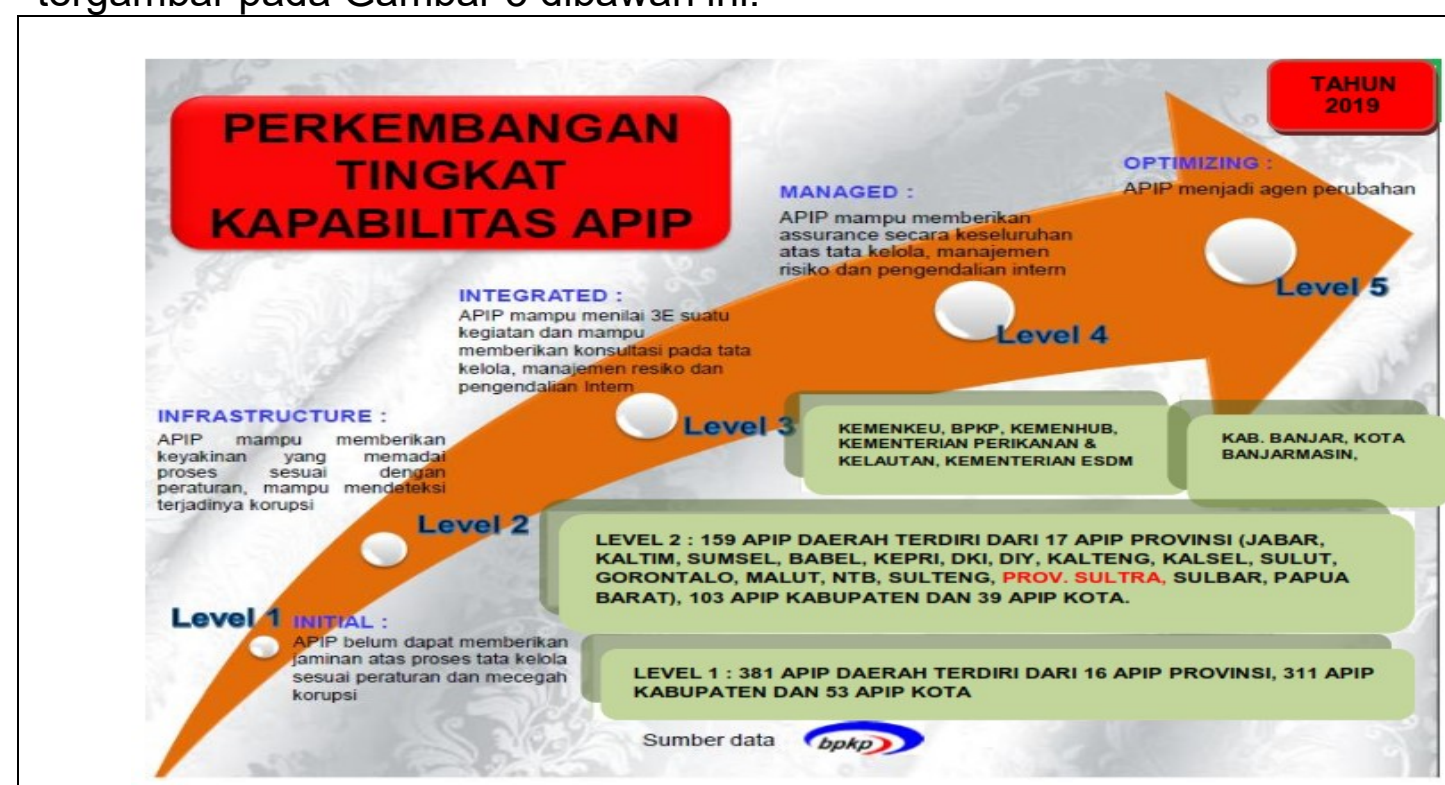

Gambar 3. Penilaian level Kapabilitas APIP Tahun 2019

\subsection{Analisis Pencapaian Kinerja}

Pencapaian indikator kinerja tersebut tidak terlepas dari proses kegiatan yang mengolah input menjadi output atau proses penyusunan kebijakan/program/kegiatan yang dianggap penting dan berpengaruh terhadap pencapaian sasaran dan tujuan. Analisis pencapaian akuntabilitas kinerja merupakan kajian analisis keberhasilan atau kegagalan serta sekaligus kendala- 
kendala sebagai penghambat pelaksanaan kegiatan instansi Pemerintah dapat dikemukakan melalui hasil perhitungan capaian (realisasi) kinerja Inspektorat Daerah Kota Baubau Tahun 2019.

Indikator menurunnya temuan audit berhubungan erat dengan meningkatnya pemahaman aparatur pengelola program dan kegiatan terhadap peraturan yang berlaku, serta meningkatnya disiplin pengelolaan keuangan terkait pelaksanaan program dan kegiatan tersebut. Persentase penurunan temuan pemeriksaan yang dicapai Inspektorat Daerah Kota Baubau termasuk dalam kategori cukup memuaskan jika dibandingkan dengan target tahunan dan kinerja tahun sebelumnya sebesar $19,83 \%$ atau dengan pencapaian kinerja sebesar $98,23 \%$.

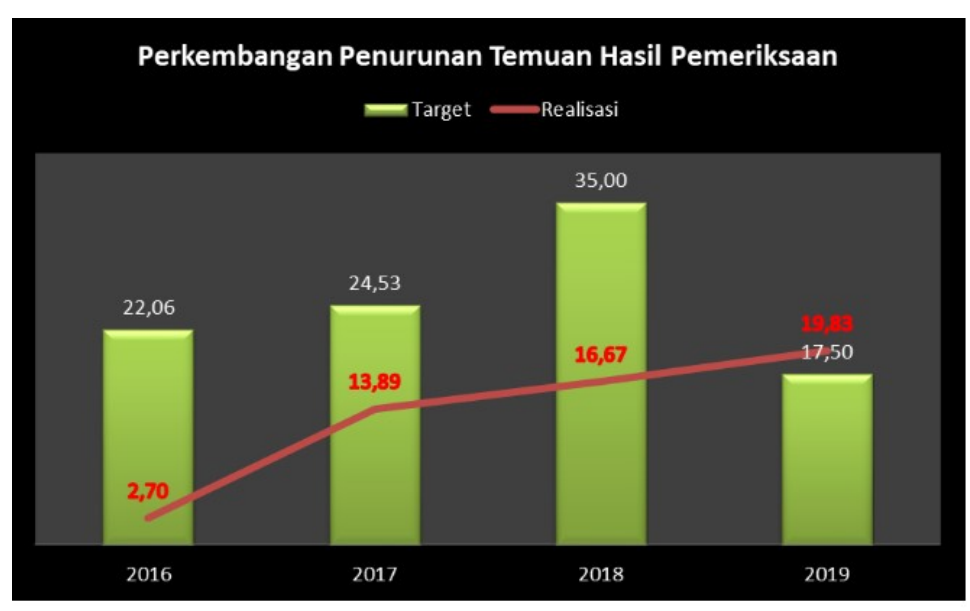

Gambar 4. Perkembangan Penurunan Temuan Hasil Pemeriksaan Inspektorat Daerah Kota Baubau (Tahun 2017 - 2019)

Indikator persentase penyelesaian tindak lanjut hasil pemeriksaan luar (BPK $\mathrm{RI}$ ) adalah $75,68 \%$ dengan pencapaian kinerja sebesar $83,50 \%$ sesuai target yang ditetapkan. Pencapaian ini sangat didukung dengan pelaksanaan kegiatan tindak lanjut temuan pengawasan dan evaluasi berkala atas temuan pengawasan di Inspektorat Daerah Kota Baubau serta itikad baik OPD untuk menindaklanjuti temuan tersebut. Indikator Persentase SKPD Lingkup Pemerintah Daerah Kota Baubau yang memperoleh Predikat Sistem AKIP CC telah tercapai sepenuhnya yaitu $65 \%$ dari target $70 \%$ SKPD yang dievaluasi.

Indikator Persentase SKPD Lingkup Pemerintah Daerah Kota Baubau yang mendapatkan Predikat Sistem AKIP $\geq$ CC telah tercapai sepenuhnya yaitu $65 \%$ dari target $70 \%$ SKPD yang dievaluasi. Sedangkan indikator Tingkat Kematangan SPIP masih berada pada Level 2 yang artinya Pemerintah Kota Baubau telah melaksanakan praktik pengendalian intern dan terdokumentasi dengan baik. Namun, evaluasi pengendalian internal dilakukan tanpa dokumentasi yang memadai. Peningkatan signifikan pada indikator ini merupakan pencapaian yang membanggakan karena mencerminkan pengendalian internal dan tata kelola organisasi yang sudah cukup baik dan efektif. Indikator ini sudah diterapkan sejak tahun 2015 dan Pemerintah Kota Baubau juga sudah mulai menerapkannya di tahun yang sama. Tingkat Kapabilitas APIP Inspektorat Daerah Kota Baubau tahun 2019 berada pada Level 2+ menuju level 3. Hal ini meningkat dari tahun sebelumnya yang berada di Level 2 dengan catatan. Hal ini tidak terlepas dari terpenuhinya elemen komponen penilaian sebagai berikut: (1) Akuntabilitas/Manajemen Kinerja yaitu disusunnya SOP reviu anggaran 
operasional pengawasan dan Laporan Kinerja serta perjanjian kinerja yang terukur, (2) Pengelolaan SDM yaitu dengan adanya komitmen pimpinan terkait jaminan pemenuhan angka kredit bagi apparat fungsional pengawasan/auditor dan (3) Budaya dan Hubungan Organisasi yang telah berada pada tataran yang sangat baik. Diharapkan pada tahun 2019 level kapabilitas APIP dapat lebih ditingkatkan sehingga dapat mencapai level 3 penuh.

Secara umum, capaian kinerja yang telah dihasilkan oleh Inspektorat Daerah Kota Baubau sesuai degan Perjanjian Kinerja tahun 2019 termuat pada Tabel 3 berikut.

Tabel 3. Capaian Kinerja Sasaran Stratetgis

\begin{tabular}{|c|c|c|c|c|c|}
\hline No & Sasaran Strategis & Indikator Kinerja & $\begin{array}{l}\text { Target } \\
(2023)\end{array}$ & $\begin{array}{l}\text { Realisasi } \\
(2019)\end{array}$ & $\begin{array}{c}\text { Capaian } \\
(\%)\end{array}$ \\
\hline \multirow[t]{4}{*}{1} & \multirow{4}{*}{$\begin{array}{l}\text { Meningkatnya } \\
\text { Kualitas Pembinaan } \\
\text { dan Pengawasan } \\
\text { Internal Pemerintah } \\
\text { Daerah }\end{array}$} & & & & \\
\hline & & $\begin{array}{l}\text { Persentase } \\
\text { Penyelesaian Tindak } \\
\text { Lanjut: }\end{array}$ & & & \\
\hline & & - Eksternal (BPK RI) & $85 \%$ & $83,50 \%$ & 98,23 \\
\hline & & $\begin{array}{l}\text { Persentase Nilai } \\
\text { SAKIP OPD minimal } \\
\text { CC }\end{array}$ & $85 \%$ & $70 \%$ & 82,35 \\
\hline \multirow[t]{2}{*}{2} & \multirow[b]{2}{*}{$\begin{array}{l}\text { Meningkatnya } \\
\text { Kualitas APIP \& } \\
\text { Efektifitas SPIP } \\
\text { dalam Rangka } \\
\text { Profesionalisme } \\
\text { Pengawasan } \\
\text { Internal }\end{array}$} & Level Maturitas SPIP & 4 & 2 & 66,67 \\
\hline & & $\begin{array}{l}\text { Level Kapabilitas } \\
\text { APIP }\end{array}$ & 4 & 2 & 66,67 \\
\hline
\end{tabular}

Sumber: LAKIP Kota Baubau Tahun 2019.

Berdasarkan hasil capaian kinerja sasaran strategis Tahun 2019 dapat dilihat bahwa seluruh indikator mengalami peningkatan capaian performance. Pencapaian tersebut memperoleh dukungan berupa komitmen yang kuat dari seluruh jajaran di Inspektorat Daerah Kota Baubau dan seluruh SKPD lingkup Pemerintah Daerah Kota Baubau. Kondisi ini juga memperoleh dukungan dari sisi penganggaran yang berdampak pada peningkatan dalam pengimplementasian program dan kegiatan, seperti termuat pada Tabel 4 berikut.

Tabel 4. Analisis Efisiensi Penggunaan Anggaran Terhadap Capaian Kinerja Tahun 2019

\begin{tabular}{|c|c|c|c|c|c|c|c|c|}
\hline \multirow{2}{*}{$\begin{array}{l}\text { Sasaran } \\
\text { Strategis }\end{array}$} & \multirow{2}{*}{$\begin{array}{l}\text { Indikator } \\
\text { Kinerja }\end{array}$} & \multicolumn{3}{|c|}{ Kinerja } & \multicolumn{2}{|c|}{ Anggaran (Rp) } & \multicolumn{2}{|c|}{$\begin{array}{c}\text { Tingkat } \\
\text { Efisiensi (\%) }\end{array}$} \\
\hline & & $\begin{array}{l}\text { Tar } \\
\text { get }\end{array}$ & $\begin{array}{l}\text { Reali } \\
\text { sasi }\end{array}$ & $\begin{array}{c}\text { Capa } \\
\text { ian } \\
(\%)\end{array}$ & Target & Realisasi & $\begin{array}{l}\text { Cap } \\
\text { aian } \\
(\%)\end{array}$ & \\
\hline \multirow[t]{2}{*}{$\begin{array}{l}\text { Meningkat } \\
\text { nya } \\
\text { Kualitas } \\
\text { Pembinaa } \\
\text { n dan } \\
\text { Pengawas }\end{array}$} & $\begin{array}{l}\text { Persentas } \\
\text { e } \\
\text { Penyelesa } \\
\text { ian Tindak } \\
\text { Lanjut: }\end{array}$ & & & & \multirow[t]{2}{*}{1.386 .146 .100} & \multirow[t]{2}{*}{1.286 .310 .578} & \multirow[t]{2}{*}{$\begin{array}{c}92,7 \\
9\end{array}$} & \multirow[t]{2}{*}{7,23} \\
\hline & -Eksternal & 85 & 83,5 & 98,2 & & & & \\
\hline
\end{tabular}




\begin{tabular}{|c|c|c|c|c|c|c|c|}
\hline \multirow{2}{*}{$\begin{array}{l}\text { an Internal } \\
\text { Pemerinta } \\
\text { h Daerah }\end{array}$} & (BPK RI) & & 0 & 3 & & & \\
\hline & $\begin{array}{l}\text { Persentas } \\
\text { e Nilai } \\
\text { SAKIP } \\
\text { OPD } \\
\text { minimal } \\
\text { CC }\end{array}$ & 85 & 70 & $\begin{array}{c}82,3 \\
5\end{array}$ & & & \\
\hline \multirow{2}{*}{$\begin{array}{l}\text { Meningkat } \\
\text { nya } \\
\text { Kualitas } \\
\text { APIP \& } \\
\text { Efektifitas } \\
\text { SPIP } \\
\text { dalam } \\
\text { Rangka } \\
\text { Profesion } \\
\text { alisme } \\
\text { Pengawas } \\
\text { an Internal }\end{array}$} & $\begin{array}{l}\text { Level } \\
\text { Maturitas } \\
\text { SPIP }\end{array}$ & 3 & 2 & $\begin{array}{c}66,6 \\
7\end{array}$ & & & \\
\hline & $\begin{array}{l}\text { Level } \\
\text { Kapabilita } \\
\text { s APIP }\end{array}$ & 3 & 2 & $\begin{array}{c}66,6 \\
7\end{array}$ & 135.025 .000 & 126.338 .000 & $\begin{array}{c}93,5 \\
6\end{array}$ \\
\hline \multicolumn{4}{|c|}{ Rata-Rata Tingkat Capaian } & $\begin{array}{c}92,2 \\
3\end{array}$ & 1.521 .171 .100 & 1.412 .648 .578 & $\begin{array}{l}92,8 \\
6\end{array}$ \\
\hline
\end{tabular}

Sumber: LAKIP Kota Baubau Tahun 2019.

Tabel di atas menunjukkan bahwa rata - rata capaian kinerja telah sebagian besar mencapai target kinerja yang ditetapkan dengan ditunjukkan pada persentase rata - rata capaian kinerja sebesar $92,23 \%$ dengan pemanfaatan anggaran terkait program strategis pengawasan sebesar $92,86 \%$ dari yang telah ditetapkan. Efisiensi penggunaan anggaran berada pada taraf cukup yaitu sebesar $7,23 \%$ dengan pencapaian sasaran strategis salah satunya terdapat pada Program Peningkatan Sistem Pengawasan Internal dan Pengendalian Pelaksanaan Kebijakan KDH dimana capaian kinerjanya sebesar 92,79\% dengan salah satu kegiatan utama yaitu Pelaksanaan Pengawasan Internal secara Berkala sebesar $100 \%$. Kondisi ini mencerminkan bahwa Inspektorat Kota Baubau telah cukup melakukan efisiensi penggunaan anggaran dalam pencapaian kinerja Tahun 2019.

\section{Kesimpulan}

Pemahaman akuntabilitas kinerja yang digambarkan melalui peningkatan kualitas sumber daya manusia dan kapabilitas APIP berada pada level 2. Komponen penilaian akuntabilitas kinerja digambarkan dengan meningkatnya kualitas pembinaan dan pengawasan internal pemerintah daerah yang diukur dengan indikator penurunan temuan audit dalam kategori cukup memuaskan jika dibandingkan dengan target tahunan dan kinerja tahun sebelumnya sebesar $19,83 \%$ atau dengan pencapaian kinerja sebesar 98,23\%. Dengan demikian, indikator Persentase SKPD Lingkup Pemerintah Kota Baubau yang memperoleh Predikat Sistem AKIP CC telah tercapai sepenuhnya, yaitu $65 \%$ dari target $70 \%$ SKPD yang dievaluasi.

Tingkat efisiensi penggunaan anggaran dalam pencapaian performance berada pada taraf cukup yaitu sebesar $7,23 \%$ dengan pencapaian sasaran strategis salah satunya terdapat pada Program Peningkatan Sistem Pengawasan Internal dan Pengendalian Pelaksanaan Kebijakan KDH. 
Adapun keterbatasan penelitian ini adalah terbatasnya ruang gerak peneliti dalam memperoleh data yang lebih banyak mengenai bagaimana proses pengawasan dalam penyusunan RPJMD sampai dengan pemantauan capaian kinerja sehingga diperoleh ouput dan outcome. Dengan demikian, saran yang dapat diberikan oleh peneliti guna meningkatkan akuntabilitas kinerja pada Pemerintah Kota Baubau adalah 1) perlu adanya policy mengenai reward and punishment bagi SKPD yang tepat waktu dan terlambat dalam penyampaian LAKIP; dan 2) perlu adanya policy mengenai akuntabilitas dan pemantauan terhadap outcome bagi pihak terkait, tidak hanya akuntabilitas terhadap output.

\section{Ucapan Terima Kasih}

Penelitian ini terlaksana dengan baik dengan dukungan civitas akademika Universitas Muhammadiyah Buton. Kami mengucapkan terima kasih kepada lbu Ernawati Malik, S.E., M.Ak, selaku Dekan Fakultas Ekonomi yang telah mendukung penuh penelitian ini. Kami juga mengucapkan terima kasih kepada Inspektur dan Pegawai Inspektorat Kota Baubau yang sangat terbuka dalam memberikan informasi dan saran yang membangun mengenai akuntabilitas kinerja pemerintah daerah.

\section{Daftar Pustaka}

Dokumen Rencana Kerja Pemerintah Daerah Kota Baubau Tahun 2018-2019.

Dokumen Rencana Kerja Pemerintah Daerah Kota Baubau Tahun 2019-2020.

Dokumen Rencana Pembangunan Jangka Menengah Daerah Kota Baubau Tahun 2018-2023.

Instruksi Presiden No. 7 tahun 1999 tentang Akuntabilitas Kinerja Instansi Pemerintah. Diakses dari http://birohukum.pu.go.id/uploads/DPU/1999/Inpres71999.pdf pada tanggal 01 Juli 2021 pukul 10.30.

Laporan Akuntabilitas Kinerja Instansi Pemerintah Daerah Kota Baubau Tahun 2019.

Laporan Akuntabilitas Kinerja Instansi Pemerintah Daerah Kota Baubau Tahun 2020.

Peraturan Walikota Baubau Nomor 25 Tahun 2017 tentang Kedudukan, Susunan Organisasi, Tugas dan Fungsi Serta Tata Kerja Inspektorat Daerah Kota Baubau.

Chaidir Iswanaji, Siti Afidatul Khotijah, M. Z. N. H. (2021). Lembaga Keungan Syariah (Buku Ajar Konsentrasi Syariah). In Penerbit Adab.

Januar, H. F. A. (2014). The Influence of Measures Supervision on Performance of the Internal Auditors to Work Motivation as an Intervening Variable (Studies in Riau Province Representative BPKP). JOM FEKON, 1(2), 1-16.

M. Zidny Nafi' Hasbi. (2019). Dampak Krisis Keuangan Global Terhadap Perbankan Di Indonesia. LISAN AL-HAL: Jurnal Pengembangan Pemikiran Dan Kebudayaan, 13(2), 385-400. https://doi.org/10.35316/lisanalhal.v13i2.602 
Pratiwi, E. T. (2019). Pengaruh Kebijakan Treatment Karyawan Terhadap Efektivitas Pengendalian Internal Dan Kualitas Laporan Keuangan Sektor Publik. Jurnal Ilmiah Akuntansi Manajemen, 1(1), 40-56. https://doi.org/10.35326/jiam.v1i1.238

Pratiwi, E. T., Abdullah, R., Abdullah, L. O. D., \& Dja'wa, A. (2020). The Effect of Budget Ratcheting on Financial and Non-Financial Performance. Advances in Economics, Business and Management Research, 120(Icmeb 2019), 23-27. https://doi.org/10.2991/aebmr.k.200205.006

Ristyana Ria. (2016). Analisis Akuntabilitas Kinerja Instansi Pemerintah Pada Pemerintah Kabupaten Ponorogo. Journal of Chemical Information and Modeling, 53(9), 1689-1699.

Waworuntu, R. H. (2014). Analisis Perubahan Sistem Penganggaran Di Indonesia Dan Pengaruhnya Pada Kinerja Inspektorat Provinsi Sulawesi Utara. Emba, 2(3), 559-569.

Sugiyono. (2016). Metode Penelitian Kuantitatif, Kualitatif dan R\&D. Bandung: PT Alfabet. 